\title{
Morpho-Genetic Screening of the Promising Rice Genotypes under Salinity Stress
}

\author{
Reza M. Emon ${ }^{1,3}$, Glenn B. Gregorio ${ }^{2}$, Adedze Y. M. Nevame ${ }^{1}$, Mirza M. Islam ${ }^{3}$, M. R. Islam² \& Fan Ye-Yang ${ }^{1}$ \\ ${ }^{1}$ Chinese National Center for Rice Improvement/State Key Laboratory of Rice Biology, China National Rice \\ Research Institute, Hangzhou, China \\ ${ }^{2}$ Plant Breeding, Genetics and Biotechnology Division, International Rice Research Institute, Philippines \\ ${ }^{3}$ Bangladesh Institute of Nuclear Agriculture, BAU Campus, Mymensingh, Bangladesh \\ Correspondence: Reza Mohammad Emon, State Key Laboratory of Rice Biology, China National Rice Research \\ Institute, No. 28 Shuidaosuo Rd., Fuyang, Hangzhou, Zhejiang, 311400, P. R. China. Tel: 86-0571-6337-0364. \\ E-mail: emonbina@yahoo.com
}

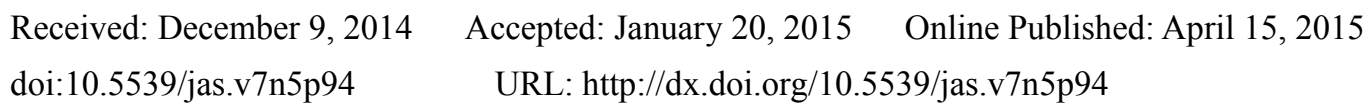

\begin{abstract}
Selection of new rice (Oryza sativa L.) variety tolerant to soil salinity is one of the most important issues to avoid salt stress in rice production. In this study, the morphological characterization was performed on 5 rice genotypes under two salt stress treatments EC8 and $12 \mathrm{dS} / \mathrm{m}$ at seedling, EC $12 \mathrm{dS} / \mathrm{m}$ at vegetative and EC8 $\mathrm{dS} / \mathrm{m}$ at reproductive stages. Morphological characters and $\mathrm{Na}^{+} / \mathrm{K}^{+}$uptake ratio were surveyed to evaluate salt stress effects. At vegetative stage, all the genotypes have survived. However, at reproductive stage all the genotypes were affected by salt stress except for the Binadhan-10 that survived the whole life cycle. A total of 160 SSR markers were used which revealed 209 alleles among the 5 rice genotypes. Interestingly, 4 SSR markers RM105, RM125, RM178 and RM549 with highest PIC (0.67) value have scored the highest level of genetic diversity value (0.72). These markers could be used to pyramiding the major and minor salt stress related genes via marker assisted selection in rice. The present investigation on variant salt stress responsiveness of 5 promising rice genotypes will be of great value in rice breeding.
\end{abstract}

Keywords: salt stress, $\mathrm{Na}^{+} / \mathrm{K}^{+}$ratio, genetic diversity, promising genotype, rice

\section{Introduction}

Rice (Oryza sativa L.) is one of the most important cereals in the world. There are about 380 million hectares of saline soils on the earth's surface and these are widely distributed in arid and semi-arid as well as seasonally dry coastal areas (Mansuri et al., 2012). Soil salinity is considered as one of the major factors that reduce plant growth in many regions in the world. Salt stress is one of the most important abiotic stresses that adversely affect natural productivity and causes significant crop loss worldwide. The salinity has affected crop production in Pakistan, India and other regions including the US. Worldwide $20 \%$ of all irrigated land is salt-affected (45 million out of 230 million ha). Eventually, soils in the arid and semiarid regions have excessive concentrations of soluble salts, which adversely affect plant growth (Aref \& Rad, 2012). In Bangladesh, 2.8 million ha of rice lands are currently affected by salinity (Islam et al., 2012) and further degradation will have detrimental consequences on food security due to limited land resources. In China, salt affected extensively soils from tropical area to temperate zones, from the coast to the inland and from the semi-arid to desert regions. Clearing the permanent deep-rooted vegetation is a major cause of salinization in non-irrigated areas; this practice causes the water table to rise and salts to accumulate in the low-lying areas. Salinity induces osmotic stress and reduces water uptake into plant roots (as less water is taken up, cell expansion growth slows down and the stomata close, ultimately affecting photosynthesis). Plants regulate water transport under salinity stress because a sufficient amount of water is indispensable for the cells to maintain their growth and vital cellular functions such as photosynthesis and metabolisms (Horie et al., 2012). Attempts to improve the salt tolerance of crops through conventional breeding program have met very limited success; due to the complexity of the salt tolerance traits, which implied morphological and physiological factors. Salinity is mainly due to the osmotic $\left(\mathrm{Na}^{+} / \mathrm{K}^{+}\right)$ imbalance in response to excessive accumulation of $\mathrm{Na}^{+}$(Gregorio et al., 1997). Evaluation of genotypes in farmers field not reliable due to heterogeneous conditions. Landraces are currently being exploited as preferred 
potential donors of salt tolerance traits because of their local adaptation. Salinity effects varied along with different growth stages in rice, thus depressed yield grain production (Mansuri et al., 2012; Shankar et al., 2011). Morpho-genetic screening of rice genotypes during all the plant developmental stages could lead to identify the salt tolerant genes. Molecular markers could now be used to evaluate their effects towards the phenotypes and thereby selecting for favorable alleles at those loci using Marker Assisted Selection scheme that aims to accelerate genetic advancement in rice (Gregorio, 1997). Due to genetic similarities between cultivated rice species, the transfer of useful genes from one to another is possible. Thus, the evaluation of genetic diversity of rice genotypes could provide valuable information for genetic improvement of salt tolerant rice. Therefore, in the present study, 5 genotypes comprised of salt sensitive, moderately tolerant and tolerant genotypes were subjected to a diversity study utilizing SSR markers. The objective of this study was to characterize genetically 5 rice genotypes and found molecular markers linked to the salt tolerance which could be used for markers assisted selection in rice breeding program.

\section{Materials and Methods}

\subsection{Plant Materials}

The five rice genotypes used were selected from seed samples collected in IRRI Plant Breeding Genetics and Biotechnology Division (PBGBD), namely: NSIC Rc222 (IR61979-138-1-3-2-3), NSIC Rc182 (IR63307-4B-4-3; BRRI dhan47), Binadhan-8 (FL449; IR66946-3R-149-1-1), Binadhan-10 (IR64197-3B-14-2), and IR64 (IR18348-36-3).

\subsection{Experiment Design}

Screening of genotypes was done under controlled environment conditions at IRRI phytotron, following the method described by Gregorio et al. (1997). A randomized complete block design with three replications was used for each entry at seedling, vegetative, and reproductive stages respectively; each plot contains 20 plants for the seedling stage and 4 plants for the vegetative and reproductive stages. The middle 5 plants of each row were sampled for evaluating the morphological data. Root length was evaluated as an average value of the 5 representative plants randomly selected from each replicate (Appendix 1). Modified standard evaluation system (SES) of visual salt injury at seedling stage (IRRI, 1996) was used to group the genotypes in different salt injury categories (Table 1).

Table 1. Modified standard evaluation system (SES) of visual salt injury at seedling stage (IRRI, 1996)

\begin{tabular}{lll}
\hline Score & Observations & Tolerance \\
\hline 1 & Normal growth, only the old leaves show white tips while no symptoms on young leaves & Highly tolerant \\
3 & Nearly normal growth, but only leaf tips burn or few leaves whitish and rolled & Tolerant \\
5 & $\begin{array}{l}\text { Growth severely retarded, most leaves rolled or severely injured and only few young } \\
\text { leaves are elongating }\end{array}$ & Moderately tolerant \\
7 & $\begin{array}{l}\text { Complete cessation of growth, most leaves dried, only few young leaves still green, some } \\
\text { plants dying }\end{array}$ & Susceptible \\
9 & Almost all plants dead or dying & Highly susceptible \\
\hline
\end{tabular}

\subsection{Screening of Rice Genotypes for Salinity Tolerance at Seedling Stage}

Salinization was imposed three weeks starting from $7^{\text {th }}$ day of seedling growth following the protocol of Gregorio (1997): two pre-germinated seeds were sown per hole on a nylon-mesh covered by styrofoam seedling float. The seedling floats were put on black trays filled with tap water and then placed inside IRRI phytotron. Three days after seeding (when seedlings are well established), water in the trays was replaced with hydroponic solution (consisting of Peter's (20-20-20) water soluble fertilizer solution, use $1 \mathrm{~g} / \mathrm{l}$ tap water with $300 \mathrm{mg}$ of $\mathrm{Fe}_{2} \mathrm{SO}_{4} \cdot 7 \mathrm{H}_{2} \mathrm{O}$ added per liter of solution). This solution can be used for 30 days. On the $7^{\text {th }}$ day, salinity treatment of $\mathrm{EC}=12 \mathrm{dS} / \mathrm{m}$ was done by adding sodium chloride $(\mathrm{NaCl})$ with the $\mathrm{pH}$ level maintained at 5.0. EC and the $\mathrm{pH}$ level were measured thereafter for each day. Due to evapotranspiration there is loss of solution in the tray. Every day, the tray was filled up with tap water and $\mathrm{pH}$ adjusted to 5.0. The $\mathrm{pH}$ of the solution must be maintained at $\mathrm{pH} 5.0$ to make available nutrients to the plants. Modified standard evaluation score was used to rating the visual symptoms of salt toxicity. This scoring discriminated the sensitive genotype from the tolerant and the moderately tolerant ones. Test entries were rated at fourteen and twenty-one days after initial salinization or when the sensitive genotype is dead. 
Nine different treatments were designed based on the rice growing stage and salinization condition:

1. Salinization at the seedling stage (impose salinity of $\mathrm{EC}=12 \mathrm{dS} / \mathrm{m}$ ) $-\mathrm{T}_{1}$

2. Salinization at the seedling stage (impose salinity of $\mathrm{EC}=8 \mathrm{dS} / \mathrm{m}$ ) $-\mathrm{T}_{2}$

3. Salinization at the vegetative stage (impose salinity of $\mathrm{EC}=12 \mathrm{dS} / \mathrm{m}$ ) $-\mathrm{T}_{3}$

4. Salinization at the reproductive stage (impose salinity of $\mathrm{EC}=8 \mathrm{dS} / \mathrm{m}$ ) $-\mathrm{T}_{4}$

5. Salinization at both seedling and vegetative stage (impose salinity of $\mathrm{EC}=8 \mathrm{dS} / \mathrm{m}$ ) $-\mathrm{T}_{5}$

6. Salinization at both seedling and reproductive stage (impose salinity of $\mathrm{EC}=8 \mathrm{dS} / \mathrm{m}$ ) $-\mathrm{T}_{6}$

7. Salinization at both vegetative and reproductive stage (impose salinity of $\mathrm{EC}=12$ and $8 \mathrm{dS} / \mathrm{m}$ ) $-\mathrm{T}_{7}$

8. Salinization at both seedling, vegetative and reproductive stage (impose salinity of $E C=8 \mathrm{dS} / \mathrm{m}$ ) $-\mathrm{T}_{8}$

9. Control (no salinization for whole life cycle) $-\mathrm{T}_{9}$

\subsection{Screening of Rice Genotypes for Salinity Tolerance at Seedling Stage and Vegetative Stage}

Salinity of EC $12 \mathrm{dS} / \mathrm{m}$ and also EC $8 \mathrm{dS} / \mathrm{m}$ was done at 1 month seedling age up to panicle initiation (PI) stage.

\subsection{Screening of Rice Genotypes at Reproductive Stage}

Salinity of EC $8 \mathrm{dS} / \mathrm{m}$ was done from PI to maturity. The culture solutions were changed to normal or salinized after each treatment stage.

\subsection{Biomass Measurement}

Fresh and dry weights of both the shoots and the roots were evaluated for analyzing biomass. The fresh weight of each genotype in each treatment (three plants per variety per replication) was measured and then plants were placed inside labeled paper bags. Drying was done inside a convection oven $\left(65^{\circ} \mathrm{C}\right)$ for three days and measured for the dry weight.

Percentage of biomass for each of the sample was obtained using the formula:

Percent biomass $=\left(\frac{\text { DryWeight }}{\text { FreshWeight }}\right) \times 100$

Percent biomass growth reduction was also obtained using the formula:

Percent growth reduction $=\left(\frac{\text { FreshWeight }(N)-\operatorname{FreshWeight}(S)}{\operatorname{FreshWeight}(N)}\right) \times 100$

Percent growth reduction $=\left(\frac{\operatorname{DryWeight}(N)-\operatorname{DryWeight}(S)}{\operatorname{Dry} W e i g h t(N)}\right) \times 100$

$\mathrm{N}$ is the normal nutrient solution and $\mathrm{S}$ is the nutrient solution with salinity.

\subsection{Measurement of Yield Parameters}

Each of the panicles per plant was threshed and measured panicle dry weight. Percent reductions in number of filled grains, unfilled grains and 100 grain weight were obtained using the formula:

Percent growth reduction $=\left(\frac{N-S}{N}\right) \times 100$

\subsection{Molecular Analysis}

DNA extraction: A modified mini-prep CetylTrimethyl Ammonium Bromide (CTAB) DNA extraction method developed at IRRI was followed in this experiment (Zheng et al., 1995). Leaf samples from all varieties were collected at 21 days after seeding. The simplified mini-scale procedure for DNA isolation was done at the Molecular Marker Applications Laboratory (MMAL), IRRI.

\subsection{SSR Marker Genotyping}

One hundred and sixty one (161) SSR markers selected from gramene website (http://www.gramene.org) were used in an extensive survey covering all 12 rice chromosomes (Mccouch et al., 2002). The total PCR reaction volume was $19 \mu \mathrm{l}$, composed of $2.0 \mu 1$ genomic DNA, $2.0 \mu 1$ 10X PCR buffer, $1.0 \mu 1 \mathrm{dNTPs}$ (contains dCTP, dGTP, dTTP and dATP each at $1 \mathrm{mM}), 1.0 \mu \mathrm{l}$ forward primer $(5 \mu \mathrm{M}), 1.0 \mu \mathrm{l}$ reverse primer $(5 \mu \mathrm{M}), 0.6 \mu \mathrm{l}$ $\mathrm{MgCl}_{2}$ (conc. of $15 \mathrm{mM}$ ), $1.0 \mu \mathrm{l}$ Taq DNA polymerase (conc. $4 \mathrm{U} / \mu \mathrm{l}$ ) and $10.4 \mu 1$ sterile nanopure water. Thermal profile in a thermocycler used was: Denaturation $94{ }^{\circ} \mathrm{C} 5 \mathrm{~min}, 35$ cycles of $94{ }^{\circ} \mathrm{C} 45 \mathrm{sec}$, annealing $55^{\circ} \mathrm{C} 45 \mathrm{sec}$ and $72{ }^{\circ} \mathrm{C} 7 \mathrm{~min}$ extension; then a final extension at $72{ }^{\circ} \mathrm{C}$ for $7 \mathrm{~min}$. After amplification, the PCR plate was stored at $4{ }^{\circ} \mathrm{C}$ until electrophoresis was done. Products were run on $8 \%$ polyacrylamide gels (PAGE) in 10X 
TBE buffer and stained with cybersafe solution for $10 \mathrm{~min}$. The stained gel was visualized by UV-trans-illuminator and photographed. Bands were scored. Cluster analysis was performed using PowerMarker ver.3.25 software (Liu \& Muse, 2005) in accordance with the unweighted pair group mean algorithm (UPGMA) utilizing the Nei and Takejaki (1983) similarity index feature. A phylogenetic map was constructed using Tree View software.

\subsection{Physiological Analysis}

$\mathrm{Na}^{+} / \mathrm{K}^{+}$analysis: Leaf samples from representative genotypes were collected and grinded. Extraction was done with $10 \mathrm{mg}$ fresh tissue and $0.1 \mathrm{~N}$ acetic acid in water bath at $90{ }^{\circ} \mathrm{C}$ for $2 \mathrm{hrs}$. The samples were then cooled overnight at room temperature. Samples were filtered and diluted with water. $\mathrm{Na}^{+} / \mathrm{K}^{+}$were determined through the use of a flame photometer. Contents in parts per million (ppm) were converted to (milimol per gram) $\mathrm{mmol} / \mathrm{g}$ by using the following formula of IRRI (Thomson et al., 2010):

Sodium content $\left(\frac{\mathrm{mmol}}{\mathrm{g}}\right)=\frac{(x)}{100 / 22.9} \times 1000$

Where, $x$ represents sodium content (ppm).

Potassium content $\left(\frac{m m o l}{g}\right)=\frac{(y)}{100 / 39.09} \times 1000$

Where, $y$ represents potassium content (ppm).

\section{Results}

\subsection{Morphological Characterization}

The five rice genotypes were evaluated for the following morphological parameters such as percentage reduction in fresh weight and dry weight of shoot and root biomass, differences in length for both root and shoot under normal and salinized treatments. The variation was observed between the genotype under salinized condition and their counterparts under normal condition for plant height, shoot length, root length, biomass, and percent reduction of growth.

\subsubsection{Salinity Screening at Seedling Stage}

With $\mathrm{EC}=12 \mathrm{dS} / \mathrm{m}$ of salinity stress, the 5 genotypes have different phenotypic response at seedling stage, which allowed to grouped them into three categories: moderately tolerant, sensitive and highly sensitive, with scores of 5, 7, and 9, respectively (Table 2) based on the modified standard evaluation score (SES) of visual salt injury at seedling stage (IRRI, 1996). On other hand, the results of salinity stress at EC $=8 \mathrm{dS} / \mathrm{m}$ also showed varied genotypic responses. The genotypes were grouped into three categories: moderately tolerant, sensitive and highly sensitive, with scores of 3, 5, and 7 respectively, based on SES scores (Table 3).

Table 2. Average salinity stress reactions at $\mathrm{EC}=12 \mathrm{dS} / \mathrm{m}$ of five rice genotypes at the seedling stage $\left(\mathrm{T}_{1}\right)$

\begin{tabular}{lllll}
\hline SI. No. & Genotypes & Designation & Score & Reaction to salinity \\
\hline 1 & NSIC Rc222 & IR61979-138-1-3-2-3 & 9 & Highly susceptible \\
2 & NSIC Rc182 or BRRI dhan47 & IR63307-4B-4-3 & 5 & Moderately tolerant \\
3 & Binadhan-8 or FL449 & IR66946-3R-149-1-1 & 5 & Moderately tolerant \\
4 & Binadhan-10 & IR64197-3B-14-2 & 7 & Susceptible \\
5 & IR64 & IR18348-36-3 & 7 & Susceptible \\
\hline
\end{tabular}

Table 3. Average salinity stress reactions at EC $=8 \mathrm{dS} / \mathrm{m}$ of five rice genotypes at the seedling stage $\left(\mathrm{T}_{2}\right)$

\begin{tabular}{lllll}
\hline Sl. No. & Genotypes & Designation & Score & Reaction to salinity \\
\hline 1 & NSIC Rc222 & IR61979-138-1-3-2-3 & 7 & Susceptible \\
2 & NSIC Rc182 or BRRI dhan47 & IR63307-4B-4-3 & 3 & Tolerant \\
3 & Binadhan-8 or FL449 & IR66946-3R-149-1-1 & 3 & Tolerant \\
4 & Binadhan-10 & IR64197-3B-14-2 & 3 & Tolerant \\
5 & IR64 & IR18348-36-3 & 5 & Moderately tolerant \\
\hline
\end{tabular}

The screening analysis showed that NSIC Rc222 had a high percent reduction in biomass for root and shoot 
fresh weight content $(52.03 \%$ and $54.43 \%)$ whereas the lowest percent reduction was obtained from Binadhan-10 (root fresh weight- $17.85 \%$ and shoot fresh weight-18.02\%). On other hand, NSIC Rc222 had a high percentage reduction for root and shoot dry weight content (53.25\% and 52.98\%). However, the lowest percent reduction obtained was $12.88 \%$ by NSIC Rc1 182 for root dry weight and $11.25 \%$ by Binadhan- 8 for shoot dry weight, respectively. All genotypes were observed to have relatively longer roots (ranging from $17.00 \mathrm{~cm}$ to $22.54 \mathrm{~cm}$ ) and shoot length (ranging from $46.00 \mathrm{~cm}$ to $62.94 \mathrm{~cm}$ ) as compared to the salinized treatments for root (ranging from $14.71 \mathrm{~cm}$ to $17.93 \mathrm{~cm}$ ) and shoot (ranging from $31.91 \mathrm{~cm}$ to $47.07 \mathrm{~cm}$ ) length (Figure 1A).

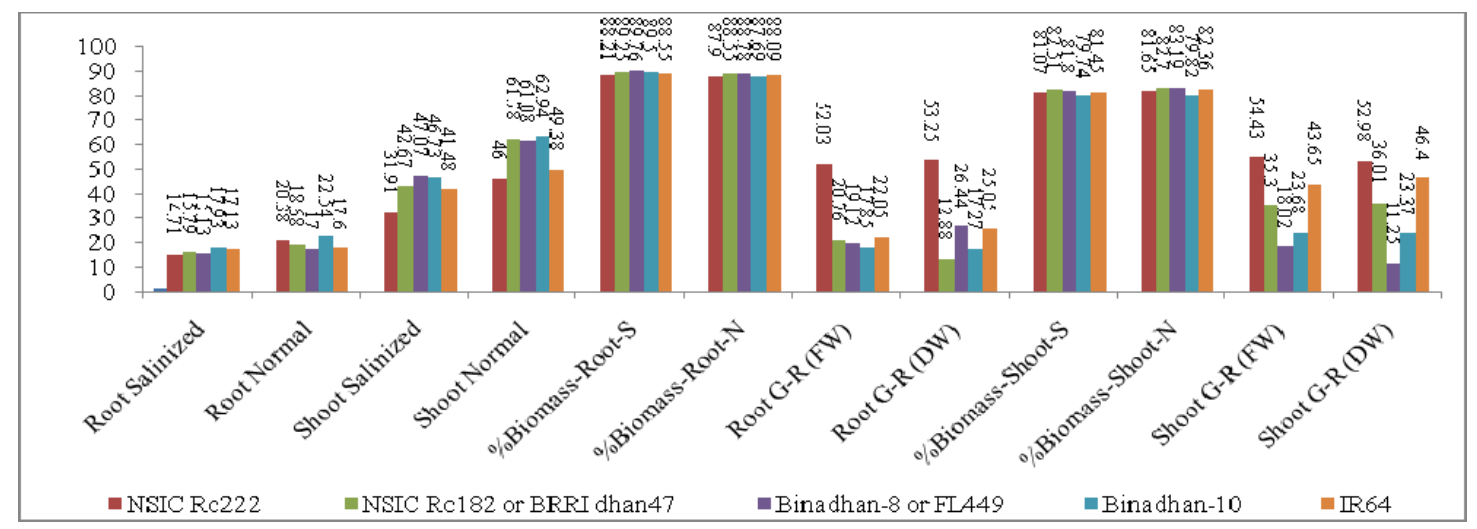

Figure 1A. Mean comparison of the each genotype of rice across all physiological traits for seedling stage $(\mathrm{EC}=8 \mathrm{dS} / \mathrm{m})$

Note. $* \mathrm{~S}=$ Salinized; $\mathrm{N}=$ Normal; G-R $=$ Growth Reduction; FW = Fresh Weight; DW = Dry Weight.

\subsubsection{Salinity Screening at Vegetative Stage}

In vegetative stage screening, Binadhan-10 had a high percent reduction for root $(67.34 \%$ and $74.18 \%)$ and shoots biomass $(79.08 \%$ and $77.68 \%$ ) based on fresh weight and dry weight, respectively while the lowest percent reduction in root biomass was obtained from NSIC Rc182 (21.32\% and 28.83\%). And the lowest percent reduction in shoot biomass content was explained by Binadhan-8 (9.97\% and $18.15 \%)$. Comprehensively, the root length of the salinized genotype ranged from $19.00 \mathrm{~cm}$ to $30.50 \mathrm{~cm}$ while that of normal treatments from $26.50 \mathrm{~cm}$ to $31.33 \mathrm{~cm}$. Meanwhile, the shoot length of the salinized genotypes ranged from $80.33 \mathrm{~cm}$ to 98.50 $\mathrm{cm}$ while that of the normal treatments from $104.00 \mathrm{~cm}$ to $111.00 \mathrm{~cm}$. The results of the seedling and vegetative stages seemed to have the same tendency as illustrated in (Figure 1B).

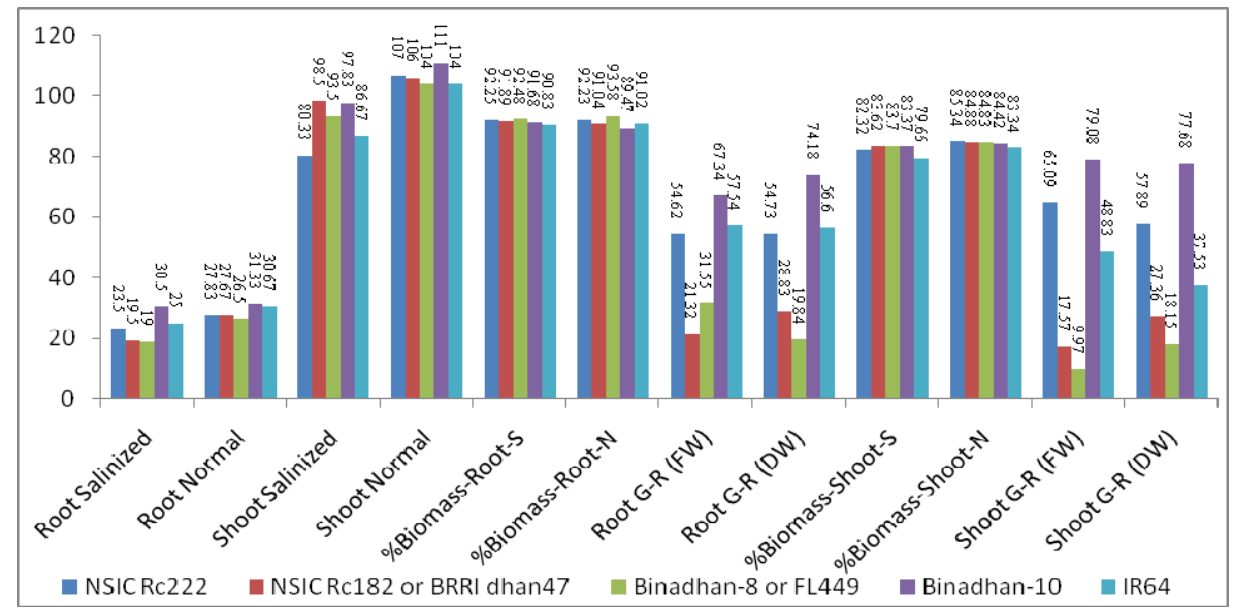

Figure 1B. Mean comparison of the each genotype of rice across all physiological traits for vegetative stage (impose salinity $\mathrm{EC}=12 \mathrm{dS} / \mathrm{m}$ at vegetative stage only)

Note. $* \mathrm{~S}=$ Salinized; $\mathrm{N}=$ Normal; G-R = Growth Reduction; FW = Fresh Weight; $\mathrm{DW}=$ Dry Weight. 


\subsubsection{Salinity Screening at Reproductive Stage}

At reproductive stage, NSIC Rc222 has expressed highest percent reduction for root biomass for $\mathrm{T}_{4}(66.84 \%), \mathrm{T}_{5}$ $(62.58 \%)$, and $\mathrm{T}_{7}(79.49 \%)$ based on dry weight content while the lowest percentage reduction was obtained in IR64 for $\mathrm{T}_{4}(3.35 \%)$, in NSIC Rc182 for $\mathrm{T}_{5}(1.61 \%)$, and in Binadhan-8 for $\mathrm{T}_{7}(0.76 \%)$. Furthermore, NSIC Rc222 had highest percent reduction in biomass for shoot fresh weight for $\mathrm{T}_{4}(36.00 \%)$ and $\mathrm{T}_{7}(79.79 \%)$ as compared to the moderately tolerant IR64 and tolerant Binadhan-8. The root length under normal condition ranged from $25.27 \mathrm{~cm}$ to $30.33 \mathrm{~cm}$ while that of the salinized condition ranged from $17.23 \mathrm{~cm}$ to $29.77 \mathrm{~cm}$. At the same time, the shoot length in normal condition ranged from $93.90 \mathrm{~cm}$ to $108.77 \mathrm{~cm}$ and that of the salinized condition ranged from $78.87 \mathrm{~cm}$ to $105.80 \mathrm{~cm}$ (Figures 1C, 1D and 1E).

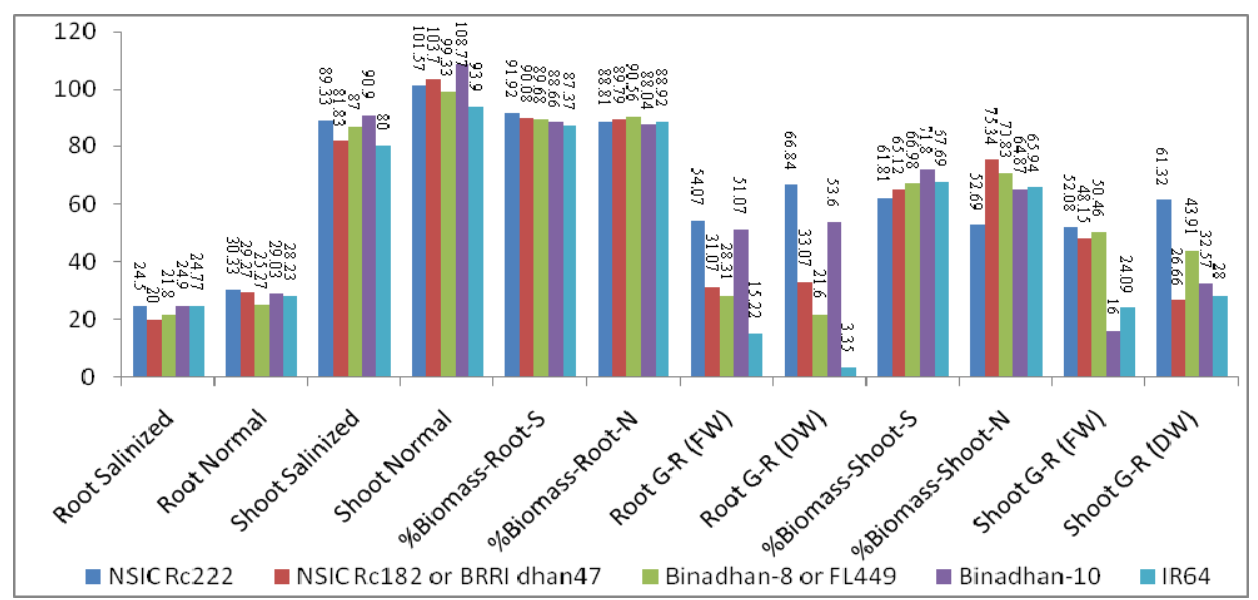

Figure 1C. Mean comparison of the each genotype of rice across all physiological traits for reproductive stage (impose salinity $\mathrm{EC}=8 \mathrm{dS} / \mathrm{m}$ at reproductive stage only)

Note. ${ }^{*} \mathrm{~S}=$ Salinized; $\mathrm{N}=$ Normal; G-R $=$ Growth Reduction; $\mathrm{FW}=$ Fresh Weight; $\mathrm{DW}=$ Dry Weight.

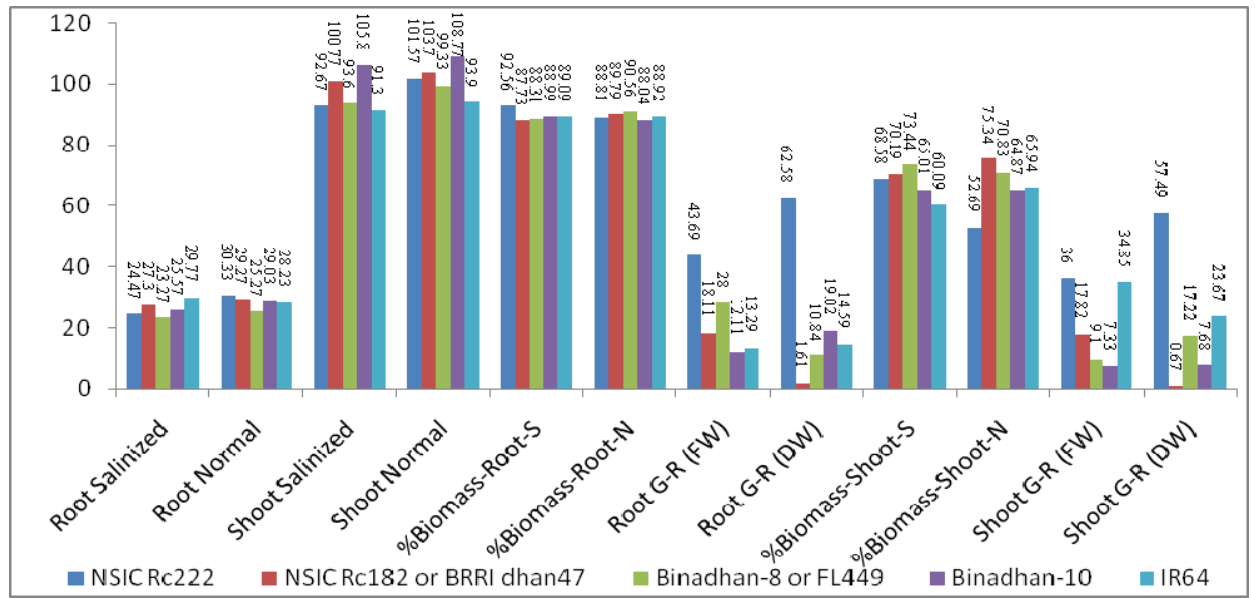

Figure 1D. Mean comparison of the each genotype of rice across all physiological traits for reproductive stage (impose salinity $\mathrm{EC}=8 \mathrm{dS} / \mathrm{m}$ at seedling and vegetative stages only)

Note. $* \mathrm{~S}=$ Salinized; $\mathrm{N}=$ Normal; $\mathrm{G}-\mathrm{R}=$ Growth Reduction; $\mathrm{FW}=$ Fresh Weight; $\mathrm{DW}=$ Dry Weight. 


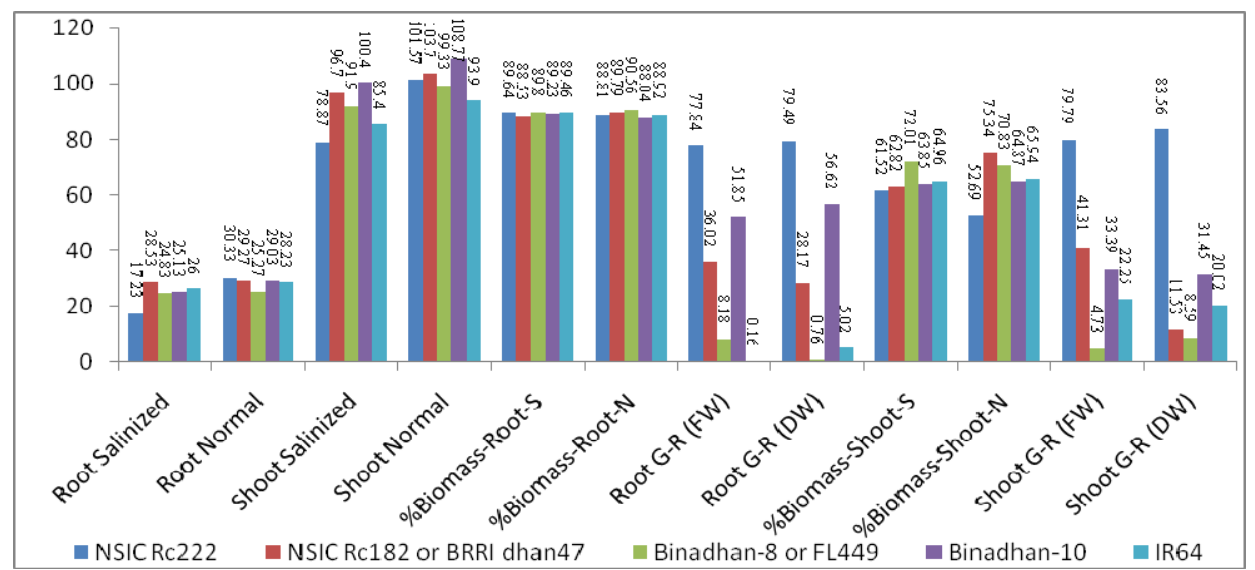

Figure 1E. Mean comparison of the each genotype of rice across all physiological traits for reproductive stage (impose salinity $\mathrm{EC}=8 \mathrm{dS} / \mathrm{m}$ at vegetative and reproductive stages only)

Note. ${ }^{*} \mathrm{~S}=$ Salinized; $\mathrm{N}=$ Normal; $\mathrm{G}-\mathrm{R}=$ Growth Reduction; $\mathrm{FW}=$ Fresh Weight; $\mathrm{DW}=$ Dry Weight.

The variable measured for assessing the effects of salinization set-up on the yield components of 5 rice genotypes were: days to flowering, panicle length, and percent reduction in filled grains number, unfilled grains number, and 1000-grain weight. Salinity causes delayed in flowering and panicle initiation. For $\mathrm{T}_{4}$ treatment, Binadhan-8 (74\%) showed highest filled grains along with NSIC Rc222 (68\%) whereas NSIC Rc182 showed the smallest value (32\%). In addition, $62 \%$ of unfilled grains number reduction was observed in NSIC Rc222 and Binadhan-10 while the lowest was for IR64 (11\%). For 1000-grain weight, highest reduction was observed for NSIC Rc182 (26.27\%) and the lowest for NSIC Rc222 (1.19\%) (Figure 1F). In case of $\mathrm{T}_{5}$, the reduction in filled and unfilled grains were $73 \%$ and $47 \%$ for NSIC Rc222, and $15 \%$ and $18 \%$ for NSIC Rc182, respectively as the two extreme values compared to others genotypes. For 1000-grain weight, highest reduction was for IR64 (9.84\%) and lowest reduction was for NSIC Rc182 (1.75\%) (Figure 1G). In $\mathrm{T}_{7}$ treatment all the varieties showed differences for all measured variables. NSIC Rc222 showed highest mean for percent reduction in both filled and unfilled grains number $(90 \%$ and $69 \%$, respectively), but Binadhan- 8 had the smallest mean $(4 \%)$. In case of 1000-grain weight NSIC Rc182 (4.94\%) had the smallest value (Figure 1H).

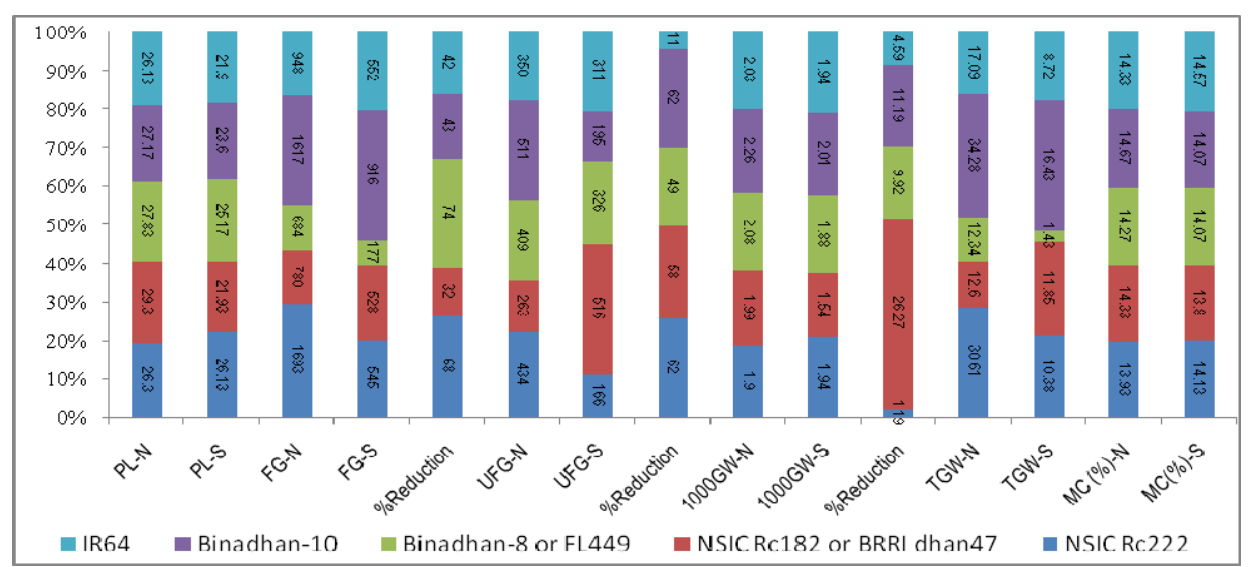

Figure 1F. Mean comparison of the each genotype of rice across all yield traits (impose salinity EC $=8 \mathrm{dS} / \mathrm{m}$ at reproductive stage only)

Note. $* \mathrm{PL}=$ Panicle length; $\mathrm{S}=$ Salinized; $\mathrm{N}=$ Normal; $\mathrm{FG}=$ Filled grain; $\mathrm{UFG}=$ Unfilled grain; $\mathrm{TGW}=$ Total grain weight; $\mathrm{MC}=$ Moisture content. 


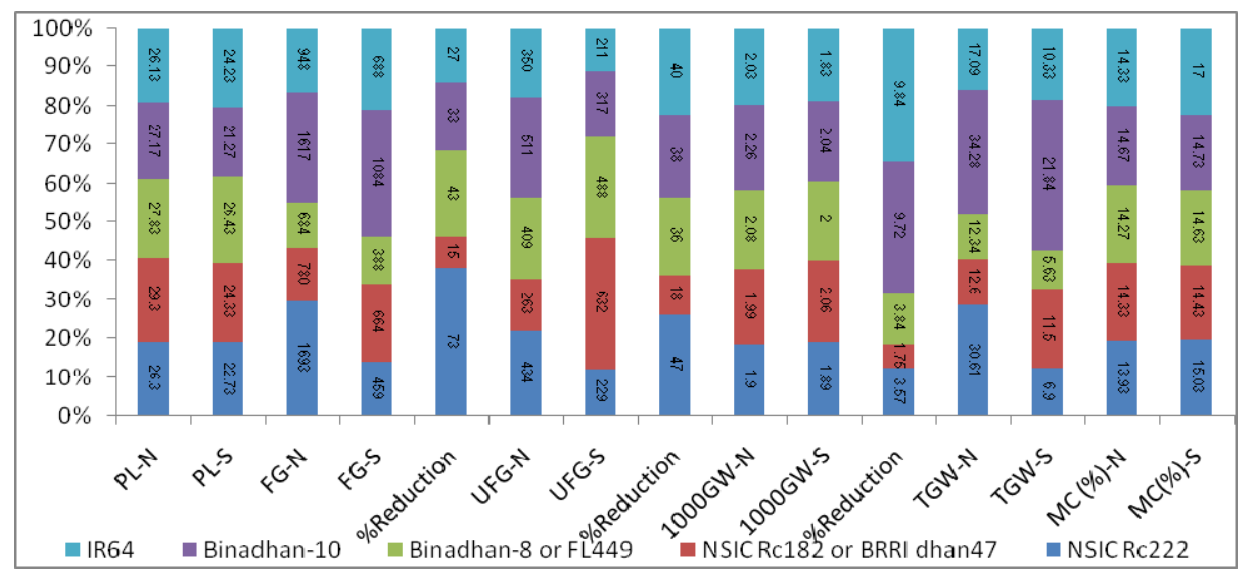

Figure 1G. Mean comparison of the each genotype of rice across all yield traits (impose salinity EC $=8 \mathrm{dS} / \mathrm{m}$ at seedling and vegetative stages only)

Note. $* \mathrm{PL}=$ Panicle length; $\mathrm{S}=$ Salinized; $\mathrm{N}=$ Normal; $\mathrm{FG}=$ Filled grain; $\mathrm{UFG}=$ Unfilled grain; $\mathrm{TGW}=$ Total grain weight; $\mathrm{MC}=$ Moisture content.

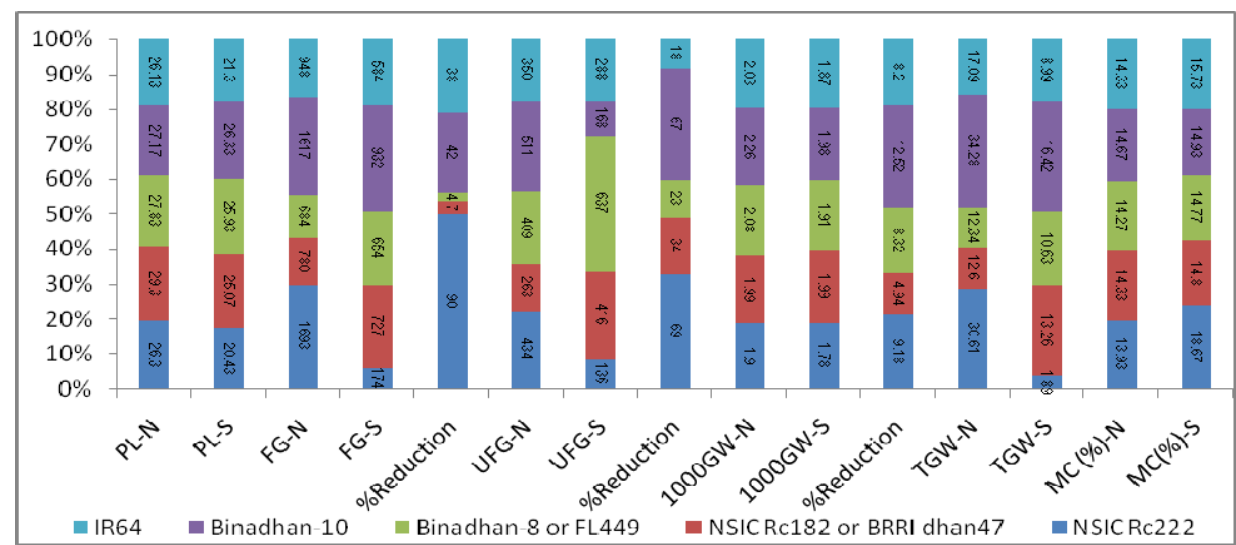

Figure $1 \mathrm{H}$. Mean comparison of the each genotype of rice across all yield traits (impose salinity EC $=8 \mathrm{dS} / \mathrm{m}$ at vegetative and reproductive stages)

Note. $* \mathrm{PL}=$ Panicle length; $\mathrm{S}=$ Salinized; $\mathrm{N}=$ Normal; $\mathrm{FG}=$ Filled grain; $\mathrm{UFG}=$ Unfilled grain; $\mathrm{TGW}=$ Total grain weight; $\mathrm{MC}=$ Moisture content.

NSIC Rc222 had a high percent reduction in biomass for shoot fresh weight such as $54.43 \%$ at seedling stage $\left(\mathrm{T}_{1}\right.$ and $\left.\mathrm{T}_{2}\right), 65.09 \%$ at vegetative stage $\left(\mathrm{T}_{3}\right)$, and $52.08 \%$ reproductive stage $\left(\mathrm{T}_{4}\right)$ screening, as compared to the tolerant NSIC Rc182 with $35.30 \%, 17.57 \%$ and $48.15 \%$, Binadhan- 8 with $18.02 \%, 9.97 \%$ and $50.46 \%$, moderately tolerant Binadhan-10 with $23.68 \%, 79.08 \%$ and $16.00 \%$, and IR64 with $43.65 \%, 48.83 \%$ and $24.09 \%$, respectively (Figures 1A, 1B and 1C). There was a relationship between the genotypes SES scores (Tables 1 and 2) and percent reduction in root-shoot biomass for fresh weight and dry weight content (Figure 1). Root and shoot length at seedling, vegetative and reproductive stages screening in all treatments were reduced in the different salinized treatments (Figures 1A, 1B, 1C, 1D and 1E). The percent reduction in dry weight and fresh weight of the root biomass was higher than that of the shoot biomass for all the genotypes.

This indicated that reduction in filled grains, unfilled grains and 1000-grain weight among the different genotypes was caused by salinity stress.

\subsection{Physiological Characterization}

The five rice genotypes were evaluated for the following physiological parameters: Shoot $\mathrm{Na}^{+} / \mathrm{K}^{+}$ratios for both normal and salinized treatments.

\subsubsection{Seedling Stage}

In the seedling stage, the ratio of $\mathrm{Na}^{+} / \mathrm{K}^{+}$in the genotypes under normal treatment were lower compared to that 
under salinized treatment. Under salinized treatment, the $\mathrm{Na}^{+} / \mathrm{K}+$ ratio was significantly different among the genotypes. The $\mathrm{Na}^{+} / \mathrm{K}^{+}$ratio of the tolerant genotypes (NSIC Rc182, Binadhan-8, Binadhan-10) and moderately tolerant genotype (IR64) was lower than that of the sensitive NSIC Rc222 (Figure 2A). The difference in the ratio of $\mathrm{Na}^{+} / \mathrm{K}^{+}$under normal condition for all genotype was not significant.

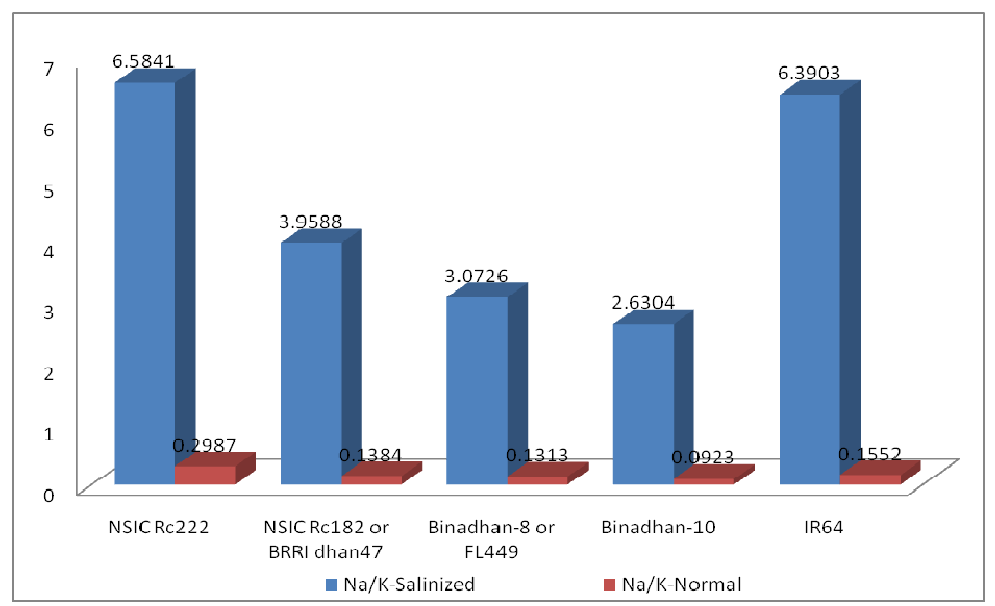

Figure 2A. Mean comparison of the each genotype of rice across $\mathrm{Na}^{+} / \mathrm{K}^{+}$absorption (impose salinity $\mathrm{EC}=8$ $\mathrm{dS} / \mathrm{m}$ at seedling stage only)

\subsubsection{Vegetative Stage}

At vegetative stage the ratio of $\mathrm{Na}^{+} / \mathrm{K}^{+}$among the genotypes under normal and salinized treatments was different. In the salinized condition, the average value of $\mathrm{Na}^{+} / \mathrm{K}^{+}$for NSIC Rc222 (0.12) and NSIC Rc182 (0.09) were slightly higher than that of the control (IR64) while Binadhan-8 (0.08) has shown similar value compared to the control(0.08). Further, the $\mathrm{Na}^{+} / \mathrm{K}^{+}$ratio of Binadhan-10 (0.06) was relatively lower than that of the control. In normal condition, 3 genotypes such as NSIC Rc222 (0.06), Binadhan-8 (0.06) and Binadhan-10 (0.07) have explained a relatively low value of $\mathrm{Na}^{+} / \mathrm{K}^{+}$while that of the NSIC Rc182 (0.13) was high as compared to the control (0.08), respectively. No difference was found in $\mathrm{Na}^{+} / \mathrm{K}^{+}$ratio for the control (IR64) under both the saline and normal condition (Figure 2B).

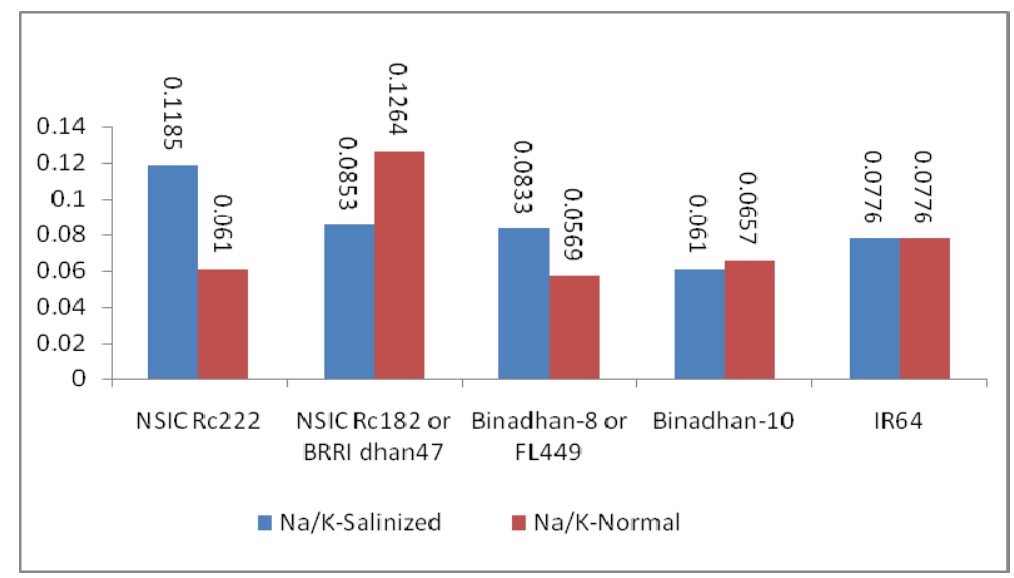

Figure 2B. Mean comparison of the each genotype of rice across $\mathrm{Na}^{+} / \mathrm{K}^{+}$absorption (impose salinity $\mathrm{EC}=12$ $\mathrm{dS} / \mathrm{m}$ at vegetative stage only)

\subsubsection{Reproductive Stage}

At the reproductive stage, genotypes have lower values of $\mathrm{Na}^{+} / \mathrm{K}^{+}$ratio under normal treatment than under salinized treatment, which varied for flag leaf and the third leaf from the top. Comparatively, the $\mathrm{Na}^{+} / \mathrm{K}+$ absorption rate in the third leaf is higher than in the flag leaf. However, the average $\mathrm{Na}^{+} / \mathrm{K}+$ values between the 
third leaf and flag leaf under normal treatment were different for all the genotypes. In reproductive stage screening, this $\mathrm{Na}^{+} / \mathrm{K}^{+}$ratio the tolerant genotypes seemed to be lower than that of sensitive genotypes. In case of flag leaf, $\mathrm{Na}^{+} / \mathrm{K}^{+}$ratio of tolerant genotypes was averagely higher compared with the normal treatment. Tolerant and moderately tolerant genotype NSIC Rc182, Binadhan-8, Binadhan-10 and IR64 had lower $\mathrm{Na}^{+} / \mathrm{K}^{+}$ratio than sensitive NSIC Rc222 in third leaf under salinized condition. In normal condition $\mathrm{Na}^{+} / \mathrm{K}^{+}$ratio also varied for all the genotypes for third leaf and for flag leaf (Figures 2C and 2D).

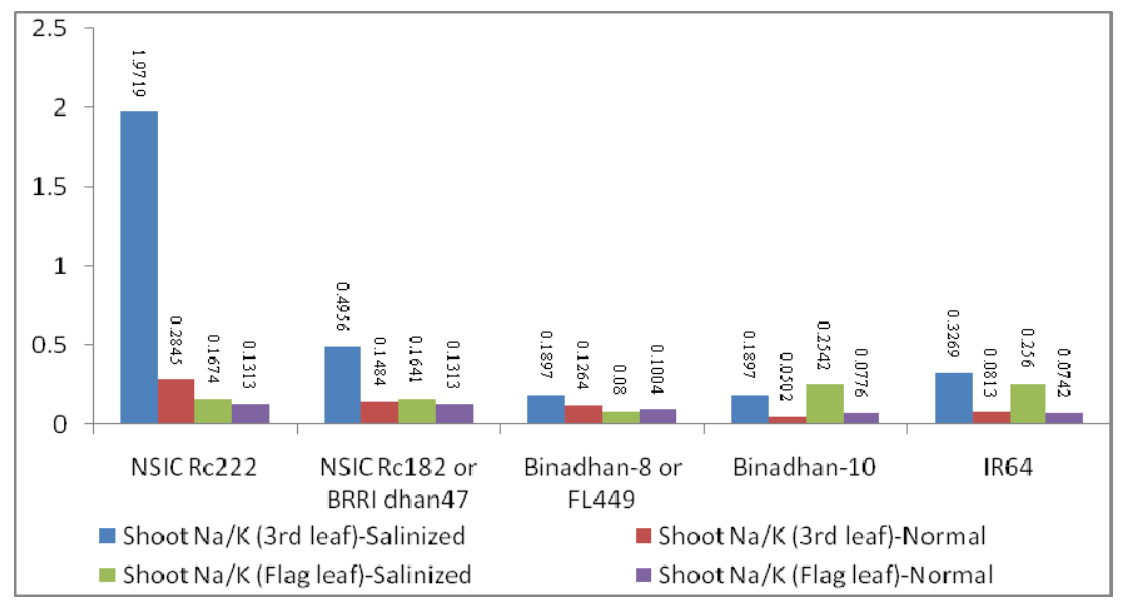

Figure 2C. Mean comparison of the each genotype of rice across $\mathrm{Na}^{+} / \mathrm{K}^{+}$for $3^{\text {rd }}$ and flag leaf (impose salinity EC $=8 \mathrm{dS} / \mathrm{m}$ at reproductive stage only)

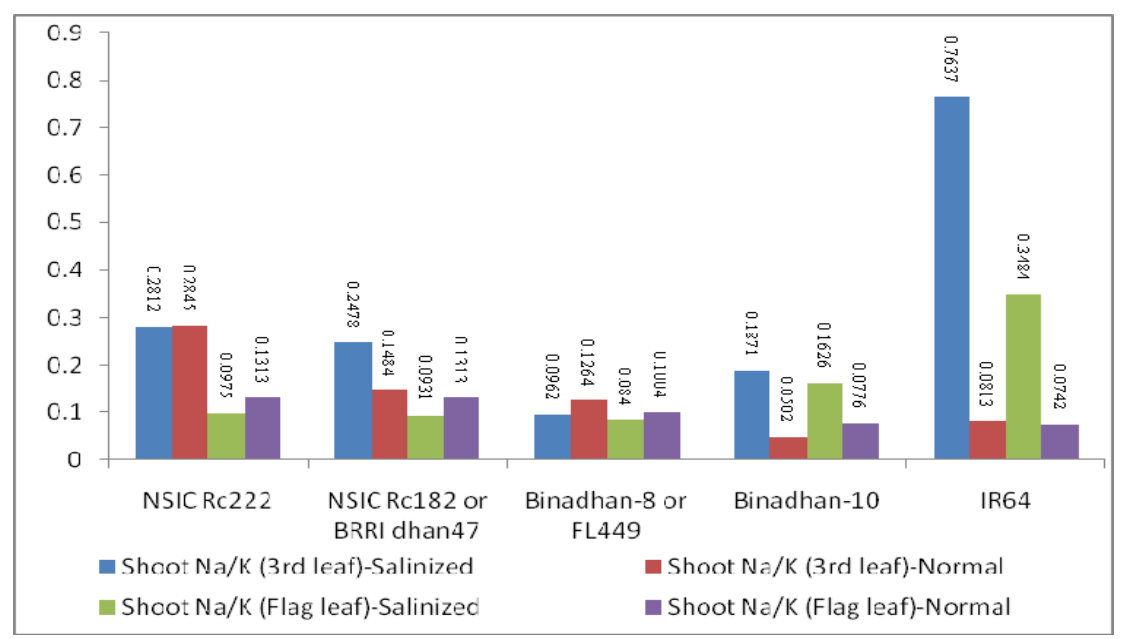

Figure 2D. Mean comparison of the each genotype of rice across $\mathrm{Na}^{+} / \mathrm{K}^{+}$for $3^{\text {rd }}$ and flag leaf (impose salinity EC $=8 \mathrm{dS} / \mathrm{m}$ at seedling and vegetative stages only)

\subsection{Molecular Characterization}

Among the 161 SSR markers used to amplify PCR products in 5 rice genotypes, 98 which showed clear bands that could be scored and used for genetic analysis. A total of 209 alleles were detected, which ranged from 1 to 4 alleles with an average of 2.13. Four markers out of the 101 amplified 4 alleles and 25 showed highest frequency of major allele. On other hand, the PIC values calculated ranged from 0.27 to 0.67 with an average of 0.41 . It is observed that the polymorphism information content (PIC) was inversely proportional to the frequency of the major allele. According to Ram et al. (2007), a PIC value higher than 0.50 indicates high degree of polymorphism. In this study, 19 SSR markers were found to score PIC value more than 0.50 , thus indicated that these markers could be used for performing genetic diversity analysis for the traits. This implied that these markers were effective for screening salinity tolerance of the 5 genotypes. Accordingly, 4 out of the 19 SSR markers have showed 0.72 as the highest level of genetic diversity value with 0.48 as mean (Table 4). 
Table 4. Statistics Allelic variation of 98 SSR loci in the 5 rice genotypes surveyed

\begin{tabular}{|c|c|c|c|c|c|c|c|c|c|}
\hline Marker & Major Allele Frequency & Genotype No & Sample Size & No. of obs. & Allele No & Availability & Gene Diversity & Heterozygosity & PIC \\
\hline RM484 & 0.60 & 3.00 & 5.00 & 5.00 & 3.00 & 1.00 & 0.56 & 0.00 & 0.50 \\
\hline RM171 & 0.40 & 3.00 & 5.00 & 5.00 & 3.00 & 1.00 & 0.64 & 0.00 & 0.56 \\
\hline RM124 & 0.40 & 3.00 & 5.00 & 5.00 & 3.00 & 1.00 & 0.64 & 0.00 & 0.56 \\
\hline RM489 & 0.80 & 2.00 & 5.00 & 5.00 & 2.00 & 1.00 & 0.32 & 0.00 & 0.27 \\
\hline RM514 & 0.60 & 2.00 & 5.00 & 5.00 & 2.00 & 1.00 & 0.48 & 0.00 & 0.36 \\
\hline RM507 & 0.60 & 3.00 & 5.00 & 5.00 & 3.00 & 1.00 & 0.56 & 0.00 & 0.50 \\
\hline RM474 & 0.80 & 2.00 & 5.00 & 5.00 & 2.00 & 1.00 & 0.32 & 0.00 & 0.27 \\
\hline RM536 & 0.80 & 2.00 & 5.00 & 5.00 & 2.00 & 1.00 & 0.32 & 0.00 & 0.27 \\
\hline RM144 & 1.00 & 1.00 & 5.00 & 5.00 & 1.00 & 1.00 & 0.00 & 0.00 & 0.00 \\
\hline RM133 & 0.80 & 2.00 & 5.00 & 5.00 & 2.00 & 1.00 & 0.32 & 0.00 & 0.27 \\
\hline RM162 & 1.00 & 1.00 & 5.00 & 5.00 & 1.00 & 1.00 & 0.00 & 0.00 & 0.00 \\
\hline RM19 & 1.00 & 1.00 & 5.00 & 5.00 & 1.00 & 1.00 & 0.00 & 0.00 & 0.00 \\
\hline RM55 & 0.40 & 3.00 & 5.00 & 5.00 & 3.00 & 1.00 & 0.64 & 0.00 & 0.56 \\
\hline RM433 & 1.00 & 1.00 & 5.00 & 5.00 & 1.00 & 1.00 & 0.00 & 0.00 & 0.00 \\
\hline RM452 & 0.40 & 3.00 & 5.00 & 5.00 & 3.00 & 1.00 & 0.64 & 0.00 & 0.56 \\
\hline RM552 & 0.60 & 3.00 & 5.00 & 5.00 & 3.00 & 1.00 & 0.56 & 0.00 & 0.50 \\
\hline RM316 & 0.60 & 3.00 & 5.00 & 5.00 & 3.00 & 1.00 & 0.56 & 0.00 & 0.50 \\
\hline RM461 & 0.80 & 2.00 & 5.00 & 5.00 & 2.00 & 1.00 & 0.32 & 0.00 & 0.27 \\
\hline RM338 & 0.60 & 2.00 & 5.00 & 5.00 & 2.00 & 1.00 & 0.48 & 0.00 & 0.36 \\
\hline RM334 & 0.40 & 3.00 & 5.00 & 5.00 & 3.00 & 1.00 & 0.64 & 0.00 & 0.56 \\
\hline RM307 & 1.00 & 1.00 & 5.00 & 5.00 & 1.00 & 1.00 & 0.00 & 0.00 & 0.00 \\
\hline RM259 & 0.70 & 3.00 & 5.00 & 5.00 & 2.00 & 1.00 & 0.42 & 0.20 & 0.33 \\
\hline RM495 & 0.40 & 3.00 & 5.00 & 5.00 & 3.00 & 1.00 & 0.64 & 0.00 & 0.56 \\
\hline RM118 & 1.00 & 1.00 & 5.00 & 5.00 & 1.00 & 1.00 & 0.00 & 0.00 & 0.00 \\
\hline RM152 & 0.60 & 3.00 & 5.00 & 5.00 & 3.00 & 1.00 & 0.56 & 0.00 & 0.50 \\
\hline RM283 & 1.00 & 1.00 & 5.00 & 5.00 & 1.00 & 1.00 & 0.00 & 0.00 & 0.00 \\
\hline RM215 & 0.80 & 2.00 & 5.00 & 5.00 & 2.00 & 1.00 & 0.32 & 0.00 & 0.27 \\
\hline RM25 & 0.80 & 2.00 & 5.00 & 5.00 & 2.00 & 1.00 & 0.32 & 0.00 & 0.27 \\
\hline RM284 & 0.80 & 2.00 & 5.00 & 5.00 & 2.00 & 1.00 & 0.32 & 0.00 & 0.27 \\
\hline RM11 & 1.00 & 1.00 & 5.00 & 5.00 & 1.00 & 1.00 & 0.00 & 0.00 & 0.00 \\
\hline RM105 & 0.40 & 4.00 & 5.00 & 5.00 & 4.00 & 1.00 & 0.72 & 0.00 & 0.67 \\
\hline RM455 & 0.40 & 3.00 & 5.00 & 5.00 & 3.00 & 1.00 & 0.64 & 0.00 & 0.56 \\
\hline RM237 & 0.40 & 3.00 & 5.00 & 5.00 & 3.00 & 1.00 & 0.64 & 0.00 & 0.56 \\
\hline RM125 & 0.40 & 4.00 & 5.00 & 5.00 & 4.00 & 1.00 & 0.72 & 0.00 & 0.67 \\
\hline RM277 & 0.60 & 3.00 & 5.00 & 5.00 & 3.00 & 1.00 & 0.56 & 0.00 & 0.50 \\
\hline RM510 & 1.00 & 1.00 & 5.00 & 5.00 & 1.00 & 1.00 & 0.00 & 0.00 & 0.00 \\
\hline RM178 & 0.40 & 4.00 & 5.00 & 5.00 & 4.00 & 1.00 & 0.72 & 0.00 & 0.67 \\
\hline RM1 & 0.80 & 2.00 & 5.00 & 5.00 & 2.00 & 1.00 & 0.32 & 0.00 & 0.27 \\
\hline RM5 & 0.60 & 3.00 & 5.00 & 5.00 & 3.00 & 1.00 & 0.56 & 0.00 & 0.50 \\
\hline RM44 & 0.60 & 2.00 & 5.00 & 5.00 & 2.00 & 1.00 & 0.48 & 0.00 & 0.36 \\
\hline RM312 & 0.60 & 3.00 & 5.00 & 5.00 & 3.00 & 1.00 & 0.56 & 0.00 & 0.50 \\
\hline RM413 & 0.80 & 2.00 & 5.00 & 5.00 & 2.00 & 1.00 & 0.32 & 0.00 & 0.27 \\
\hline RM13 & 0.60 & 2.00 & 5.00 & 5.00 & 2.00 & 1.00 & 0.48 & 0.00 & 0.36 \\
\hline RM10772 & 0.60 & 3.00 & 5.00 & 5.00 & 3.00 & 1.00 & 0.56 & 0.00 & 0.50 \\
\hline RM13332 & 0.40 & 3.00 & 5.00 & 5.00 & 3.00 & 1.00 & 0.64 & 0.00 & 0.56 \\
\hline RM140 & 0.60 & 3.00 & 5.00 & 5.00 & 3.00 & 1.00 & 0.56 & 0.00 & 0.50 \\
\hline
\end{tabular}




\begin{tabular}{|c|c|c|c|c|c|c|c|c|c|}
\hline RM562 & 0.60 & 2.00 & 5.00 & 5.00 & 2.00 & 1.00 & 0.48 & 0.00 & 0.36 \\
\hline RM10764 & 0.80 & 2.00 & 5.00 & 5.00 & 2.00 & 1.00 & 0.32 & 0.00 & 0.27 \\
\hline RM127 & 0.60 & 2.00 & 5.00 & 5.00 & 2.00 & 1.00 & 0.48 & 0.00 & 0.36 \\
\hline RM493 & 1.00 & 1.00 & 5.00 & 5.00 & 1.00 & 1.00 & 0.00 & 0.00 & 0.00 \\
\hline RM10684 & 0.60 & 2.00 & 5.00 & 5.00 & 2.00 & 1.00 & 0.48 & 0.00 & 0.36 \\
\hline RM20224 & 0.60 & 2.00 & 5.00 & 5.00 & 2.00 & 1.00 & 0.48 & 0.00 & 0.36 \\
\hline RM10745 & 1.00 & 1.00 & 5.00 & 5.00 & 1.00 & 1.00 & 0.00 & 0.00 & 0.00 \\
\hline RM3843 & 0.60 & 3.00 & 5.00 & 5.00 & 3.00 & 1.00 & 0.56 & 0.00 & 0.50 \\
\hline RM3206f & 0.40 & 3.00 & 5.00 & 5.00 & 3.00 & 1.00 & 0.64 & 0.00 & 0.56 \\
\hline RM1287 & 0.70 & 3.00 & 5.00 & 5.00 & 2.00 & 1.00 & 0.42 & 0.20 & 0.33 \\
\hline RM6329 & 0.80 & 2.00 & 5.00 & 5.00 & 2.00 & 1.00 & 0.32 & 0.00 & 0.27 \\
\hline RM7075 & 0.40 & 3.00 & 5.00 & 5.00 & 3.00 & 1.00 & 0.64 & 0.00 & 0.56 \\
\hline RM315 & 1.00 & 1.00 & 5.00 & 5.00 & 1.00 & 1.00 & 0.00 & 0.00 & 0.00 \\
\hline RM428 & 0.40 & 3.00 & 5.00 & 5.00 & 3.00 & 1.00 & 0.64 & 0.00 & 0.56 \\
\hline RM548 & 1.00 & 1.00 & 5.00 & 5.00 & 1.00 & 1.00 & 0.00 & 0.00 & 0.00 \\
\hline RM554 & 1.00 & 1.00 & 5.00 & 5.00 & 1.00 & 1.00 & 0.00 & 0.00 & 0.00 \\
\hline RM533 & 0.80 & 2.00 & 5.00 & 5.00 & 2.00 & 1.00 & 0.32 & 0.00 & 0.27 \\
\hline RM149 & 0.40 & 3.00 & 5.00 & 5.00 & 3.00 & 1.00 & 0.64 & 0.00 & 0.56 \\
\hline RM431 & 1.00 & 1.00 & 5.00 & 5.00 & 1.00 & 1.00 & 0.00 & 0.00 & 0.00 \\
\hline RM520 & 0.60 & 2.00 & 5.00 & 5.00 & 2.00 & 1.00 & 0.48 & 0.00 & 0.36 \\
\hline RM466 & 0.60 & 2.00 & 5.00 & 5.00 & 2.00 & 1.00 & 0.48 & 0.00 & 0.36 \\
\hline RM122 & 0.60 & 3.00 & 5.00 & 5.00 & 3.00 & 1.00 & 0.56 & 0.00 & 0.50 \\
\hline RM492 & 0.60 & 3.00 & 5.00 & 5.00 & 3.00 & 1.00 & 0.56 & 0.00 & 0.50 \\
\hline RM477 & 0.60 & 2.00 & 5.00 & 5.00 & 2.00 & 1.00 & 0.48 & 0.00 & 0.36 \\
\hline RM555 & 0.80 & 2.00 & 5.00 & 5.00 & 2.00 & 1.00 & 0.32 & 0.00 & 0.27 \\
\hline RM188 & 0.60 & 2.00 & 5.00 & 5.00 & 2.00 & 1.00 & 0.48 & 0.00 & 0.36 \\
\hline RM350 & 0.60 & 2.00 & 5.00 & 5.00 & 2.00 & 1.00 & 0.48 & 0.00 & 0.36 \\
\hline RM305 & 0.60 & 2.00 & 5.00 & 5.00 & 2.00 & 1.00 & 0.48 & 0.00 & 0.36 \\
\hline RM575 & 0.60 & 2.00 & 5.00 & 5.00 & 2.00 & 1.00 & 0.48 & 0.00 & 0.36 \\
\hline RM441 & 1.00 & 1.00 & 5.00 & 5.00 & 1.00 & 1.00 & 0.00 & 0.00 & 0.00 \\
\hline RM427 & 0.80 & 2.00 & 5.00 & 5.00 & 2.00 & 1.00 & 0.32 & 0.00 & 0.27 \\
\hline RM488 & 0.60 & 2.00 & 5.00 & 5.00 & 2.00 & 1.00 & 0.48 & 0.00 & 0.36 \\
\hline RM279 & 0.40 & 3.00 & 5.00 & 5.00 & 3.00 & 1.00 & 0.64 & 0.00 & 0.56 \\
\hline RM294 & 0.40 & 3.00 & 5.00 & 5.00 & 3.00 & 1.00 & 0.64 & 0.00 & 0.56 \\
\hline RM341 & 0.80 & 2.00 & 5.00 & 5.00 & 2.00 & 1.00 & 0.32 & 0.00 & 0.27 \\
\hline RM553 & 1.00 & 1.00 & 5.00 & 5.00 & 1.00 & 1.00 & 0.00 & 0.00 & 0.00 \\
\hline RM274 & 1.00 & 1.00 & 5.00 & 5.00 & 1.00 & 1.00 & 0.00 & 0.00 & 0.00 \\
\hline RM172 & 0.60 & 2.00 & 5.00 & 5.00 & 2.00 & 1.00 & 0.48 & 0.00 & 0.36 \\
\hline RM110 & 0.60 & 3.00 & 5.00 & 5.00 & 3.00 & 1.00 & 0.56 & 0.00 & 0.50 \\
\hline RM234 & 1.00 & 1.00 & 5.00 & 5.00 & 1.00 & 1.00 & 0.00 & 0.00 & 0.00 \\
\hline RM267 & 1.00 & 1.00 & 5.00 & 5.00 & 1.00 & 1.00 & 0.00 & 0.00 & 0.00 \\
\hline RM306 & 1.00 & 1.00 & 5.00 & 5.00 & 1.00 & 1.00 & 0.00 & 0.00 & 0.00 \\
\hline RM523 & 1.00 & 1.00 & 5.00 & 5.00 & 1.00 & 1.00 & 0.00 & 0.00 & 0.00 \\
\hline RM549 & 0.40 & 4.00 & 5.00 & 5.00 & 4.00 & 1.00 & 0.72 & 0.00 & 0.67 \\
\hline RM206 & 0.60 & 2.00 & 5.00 & 5.00 & 2.00 & 1.00 & 0.48 & 0.00 & 0.36 \\
\hline RM406 & 0.80 & 2.00 & 5.00 & 5.00 & 2.00 & 1.00 & 0.32 & 0.00 & 0.27 \\
\hline RM450 & 0.60 & 2.00 & 5.00 & 5.00 & 2.00 & 1.00 & 0.48 & 0.00 & 0.36 \\
\hline RM278 & 1.00 & 1.00 & 5.00 & 5.00 & 1.00 & 1.00 & 0.00 & 0.00 & 0.00 \\
\hline
\end{tabular}




\begin{tabular}{llllllllll}
\hline RM511 & 1.00 & 1.00 & 5.00 & 5.00 & 1.00 & 1.00 & 0.00 & 0.00 & 0.00 \\
RM425 & 1.00 & 1.00 & 5.00 & 5.00 & 1.00 & 1.00 & 0.00 & 0.00 & 0.00 \\
RM288 & 0.60 & 3.00 & 5.00 & 5.00 & 3.00 & 1.00 & 0.56 & 0.00 & 0.50 \\
RM454 & 0.80 & 2.00 & 5.00 & 5.00 & 2.00 & 1.00 & 0.32 & 0.00 & 0.27 \\
Mean & $\mathbf{0 . 7 0}$ & $\mathbf{2 . 1 5}$ & $\mathbf{5 . 0 0}$ & $\mathbf{5 . 0 0}$ & $\mathbf{2 . 1 3}$ & $\mathbf{1 . 0 0}$ & $\mathbf{0 . 3 7}$ & $\mathbf{0 . 0 0}$ & $\mathbf{0 . 3 2}$ \\
\hline
\end{tabular}

\subsubsection{Genetic Similarity Analysis Using UPGMA}

The UPGMA was constructed in this study based on genetic similarity values of the SSR markers alleles from all the rice genotypes. The Result showed two major groups, group I and II. The cluster analysis showed significant genetic variation among the rice genotypes studied. The first group clustered NSIC Rc222 as salt sensitive genotype while the second group included the genotypes Binadhan-8, NSIC Rc182, Binadhan-10 and IR64 (Figures $3 \mathrm{~A}$ and $3 \mathrm{~B}$ ) with relatively tolerant ability against salt stress.

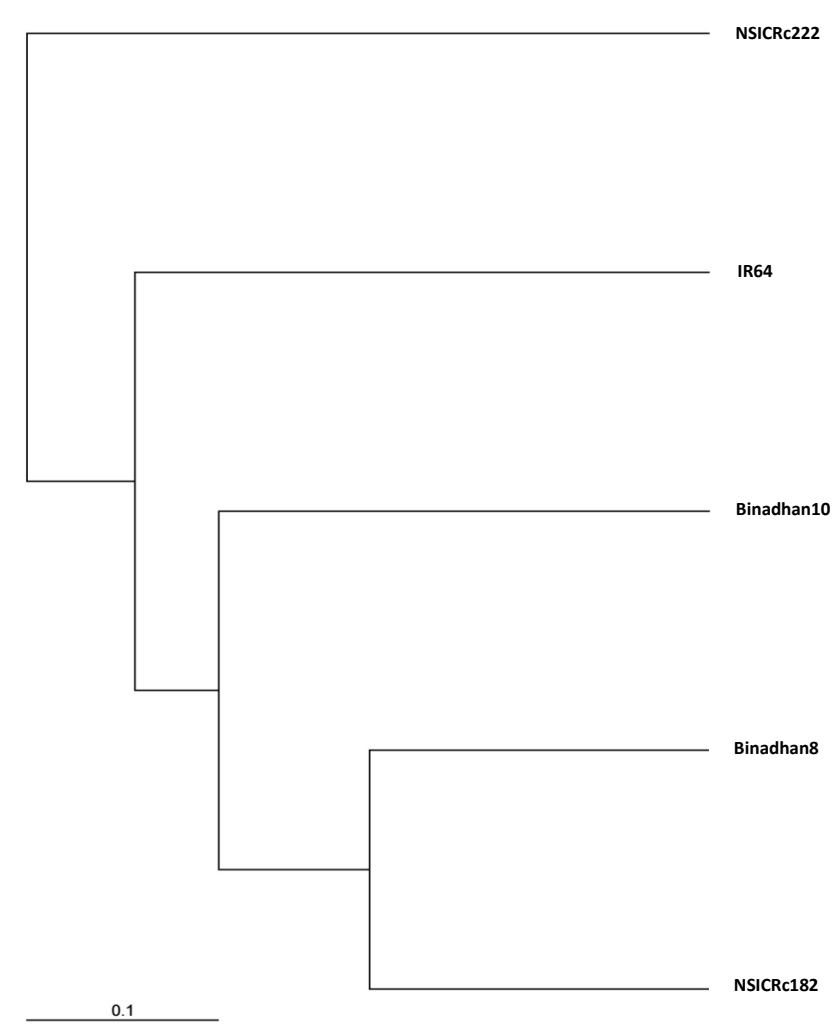

Figure 3A. Dendrogram of 5 rice genotypes showing the genetic similarity based on SSR marker using the UPGMA cluster analysis 


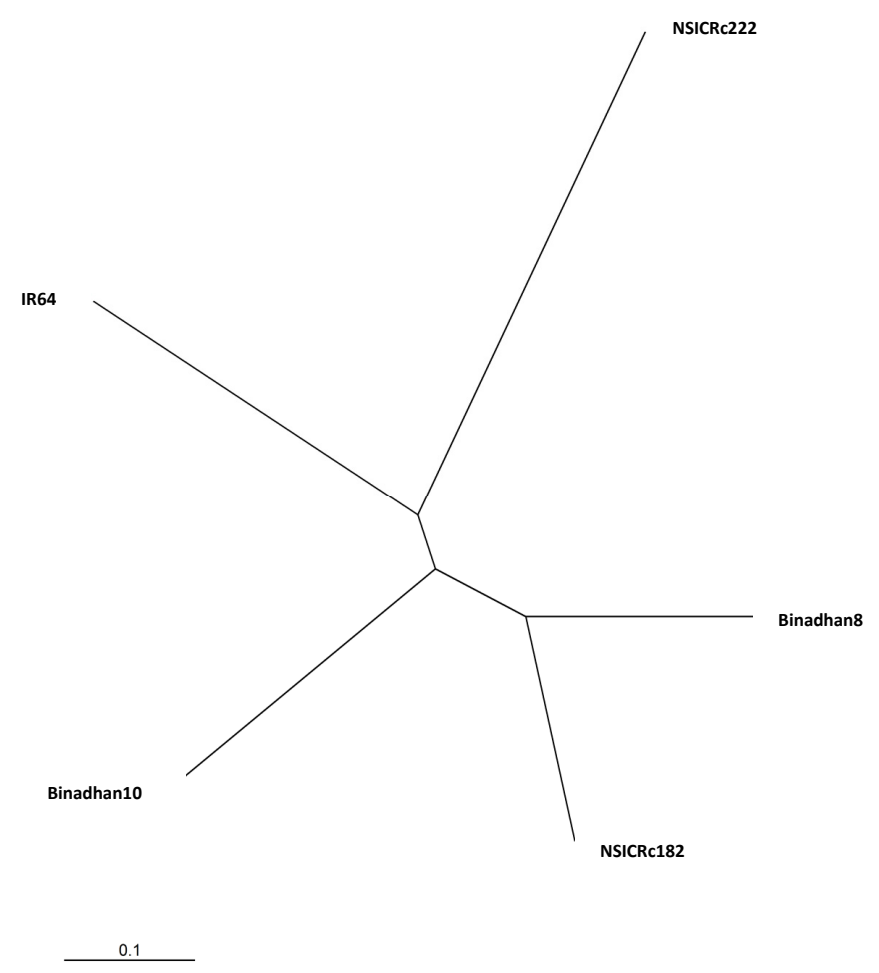

Figure 3B. Unrooted neighbor joining tree showing the genetic distance of 5 rice genotypes

\section{Discussion}

In salinized condition, during seedling, vegetative and reproductive stages, the varieties were observed to have the longest number of days to flowering than control ones. These results were similar to that found by Maligalig (2012). Morphologically, it was noted that the more sensitive genotype NSIC Rc222 had a high percent reduction in biomass for shoot and root fresh weight under stress compared to others genotypes. Singh et al. (2010) showed that the reduction in fresh and dry weight of shoot constituted a response of the rice sensitive variety to the severe salinity stress. The percent reduction in fresh weight was observed to be higher among the genotypes than percent reduction in dry weight content. These results also supported the findings of Dwivedi and Misra (2004). The yield loss was previously observed also by Aref and Rad (2012) and Maligalig (2012) in rice under salinity stress. Accordingly, it was observed that the genotypes tolerant to salinity have longer root and shoot lengths than the salt stressed genotypes. This indicates that an excessive dosage of salt in plant might impair the plant biomass production.

On other hand, tolerant varieties intake less $\mathrm{Na}^{+}$and more $\mathrm{K}^{+}$, but the sensitive ones show the reverse tendency. Nevertheless, all the genotype under salinity stress intake $\mathrm{Na}^{+} / \mathrm{K}^{+}$more than that under the control. It is understandable that plant under salinity stress absorb more sodium ion. In this study, we observed that the $\mathrm{Na}^{+} / \mathrm{K}^{+}$uptake values were higher in third leaf than the flag leaf. These results indicate that the different genotypes showed variation for the different stages under salinization for physiological traits, $\mathrm{Na}^{+} / \mathrm{K}^{+}$uptake and yield components. Therefore, it is obvious that the different genotypes were adversely affected by salt. It is reported that sodium above threshold levels in cytoplasmic cause toxic effects and thereby affects agricultural productivity (Blumwald et al., 1999). This could be one of the principal reason why the plant that elevated uptake of $\mathrm{Na}^{+} / \mathrm{K}^{+}$have exhibited salinity toxicity effects. For example, the $\mathrm{Na}^{+} / \mathrm{K}^{+}$ratios of genotype and Binadhan-10 are relatively lower than sensitive NSIC Rc222, thereby resulting less effects on biomass and yield components. The absorption rate of $\mathrm{Na}^{+} / \mathrm{K}^{+}$in third leaf is comparatively higher than the flag leaf, suggesting that the rice third leaf may be an important indicator in salinity stress evaluation. In addition, rice third leaf maybe the site of salinity sensation or the transient storage of the salt in plant.

It is obvious that the salinity sensitivity may varied with genotype, growth stage and salinity dosage. All the genotypes survived at vegetative stage irrespective of salinity dose; however, a difference is still observed in comparison with control especially for root and shoots growth. On other hand, at the reproductive stage, the 
salinity treatment affected severely all the plant except for Binadhan-10 which also exhibited some salinity effect such as incompletely filled grains formation. This result indicated that a rice plant is more sensitive to salt stress during panicle initiation and grain formation. NSIC Rc222 was highly sensitive at seedling, vegetative and reproductive stages, which implied that this genotype could be used as sensitive genotype in functional analysis of salinity tolerant gene or as positive control under salinity experiments.

Furthermore, to characterize genetically the genotypes for their salt tolerance ability, we have performed genetic analysis by using SSR markers. Accordingly, it was found that the more tolerant genotypes NSIC Rc182 and Binadhan- 8 were closer as revealed by SSR markers. The tolerant Binadhan-10 and moderately tolerant IR64 were placed at different cluster but nearly closed while the sensitive NSIC Rc222 was distant from them genetically. In addition, the tolerant and moderately tolerant genotype seemed to be grouped together. All the genotype used in this present investigation could be considered in any salt stress experiment in rice. Salinity stress is a complex character affecting the plant growth and development, physiological and morphological traits, osmotic adjustment. Many genes or gene families maybe involve in this abiotic stress responsiveness. Therefore, 4 SSR markers RM105, RM125, RM178 and RM549 identified in this study might be of great importance for the genetic diversity and allelic interaction studies between rice genotypes in salt tolerance improvement. Because this work was not exhaustive in terms of number of SSR markers and genomic coverage, subsequent study implying more SSR markers with full genome coverage is essential for more understanding the genetic network that controlled salt stress tolerance in rice.

Table 5. Frequency based distance

\begin{tabular}{llllll}
\hline OTU & Binadhan10 & Binadhan8 & IR64 & NSICRc182 & NSICRc222 \\
\hline Binadhan10 & 0.00 & - & - & - & - \\
Binadhan8 & 0.40 & 0.00 & - & - & - \\
IR64 & 0.40 & 0.51 & 0.00 & - & - \\
NSICRc182 & 0.40 & 0.28 & 0.48 & 0.00 & - \\
NSICRc222 & 0.58 & 0.55 & 0.51 & 0.53 & 0.00 \\
\hline
\end{tabular}

\section{References}

Aref, F., \& Rad, H. E. (2012). Physiological characterization of rice under salinity stress during vegetative and reproductive stages. Indian J. Sci. Technol., 4, 2578-2586.

Blumwald, E., Gilad, A. S., \& Apse, M. P. (1999). Sodium transport in plant cells. BBA, 1465, $140-151$. http://dx.doi.org/10.1016/S0005-2736(00)00135-8

Gregorio, G. B. (1997). Tagging salinity tolerance genes in rice using amplified fragment length polymorphism (AFLP) (Ph.D. dissertation, p. 84). College, Laguna, Philippines: UPLB, Philippines.

Gregorio, G. B., Senadhira, D., \& Mendoza, R. D. (1997). Screening for rice salinity tolerance. IRRI Discussion paper Series No. 22. IRRI, Philippines.

Horie, T., Karachara, I., \& Katsuhara, M. (2012). Salinity tolerance mechanisms in glycophytes: An overview with the central focus on rice plants. Rice, 5(11), 1.

International Rice Research Institute (IRRI). (1996). Standard evaluation system for rice (4th ed., p. 52). IRRI, Philippines.

Islam, M. M., Begum, S. N., Emon, R. M., Halder, J., \& Manidas, A. C. (2012). Carbon isotope discrimination in rice under salt affected conditions in Bangladesh. IAEA-TECDOC, 1617, 7-23.

Liu, K., \& Muse, S. V. (2005). Powermarker: Integrated analysis environment for genetic marker data. IJB, 21, 2128-2129.

Maligalig, A. F. C. (2012). Assessing the salinity tolerance of selected rice (Oryza sativa L.) varieties at the seedling and vegetative growth stages and genetic characterization using single nucleotide polymorphisms (B.S. Theis, p. 26). Genetics and Molecular Biology Division. UPLB, Philippines.

Mansuri, S. M., Jelodar, N. B., \& Bagheri, N. (2012). Evaluation of rice genotypes to salt stress in different growth stages via phenotypic and random amplified polymorphic DNA (RAPD) marker assisted selection. $A J B, 39,9362-9372$. 
Mccouch, S. R., Declerck, G., Teytelman, L., Xu, Y., Lobos, K., Walton, M., ... Stein, L. (2002). Development and mapping of 2240 new SSR markers for rice (Oryza sativa L.). DNA Research, 9, 199-207. http://dx.doi.org/10.1093/dnares/9.6.199

Misra, N., \& Dwivedi, U. N. (2004). Genotyping difference in salinity tolerance of green gram cultivars. PLS, $166,1135-1142$.

Nei, M., \& Takezaki, N. (1983). Estimation of genetic distances and phylogenetic trees from DNA analysis (pp. 405-412). Proc $5^{\text {th }}$ World Cong Genet ApplLivstock Prod.

Ram, S., Thiruvengadam, V., \& Vinod, K. (2007). Genetic diversity among cultivars land races and wild relatives of rice revealed by microsatellite markers. J. Appl. Genet., 48, 335-337. http://dx.doi.org/10.1007/BF03195230

Sankar, P. D., Arabi, M. S., \& Selvaraj, C. I. (2011). Rice breeding for salinity tolerance. Res. Biotech., 2, 1-10.

Singh, R. K., Redona, E., \& Refuerzo, L. (2010). Breeding efforts in rice for salinity tolerance. In A. Pareek, S. K. Sopory, H. J. Bohnert \& Govindjee (Eds.), Abiotic stress adaptation in plants: Physiological, molecular and genomic foundation (pp. 387-415). Netherlands: Springer.

Thomson, M. J., Ocampo, M., Egdane, J., Rahman, M. A., Sajise, A. G., Adorada, D. L., ... Ismail, A. M. (2010). Characterizing the Saltol Quantitative Trait Locus for Salinity Tolerance in Rice. Rice. http://dx.doi.org/10.1007/s12284-010-9053-8.

Zheng, K., Huang, N., Bennett, J., \& Khush, G. S. (1995). PCR-based marker assisted selection in rice breeding (pp. 16-18). IRRI. Manila.

\section{Appendix}

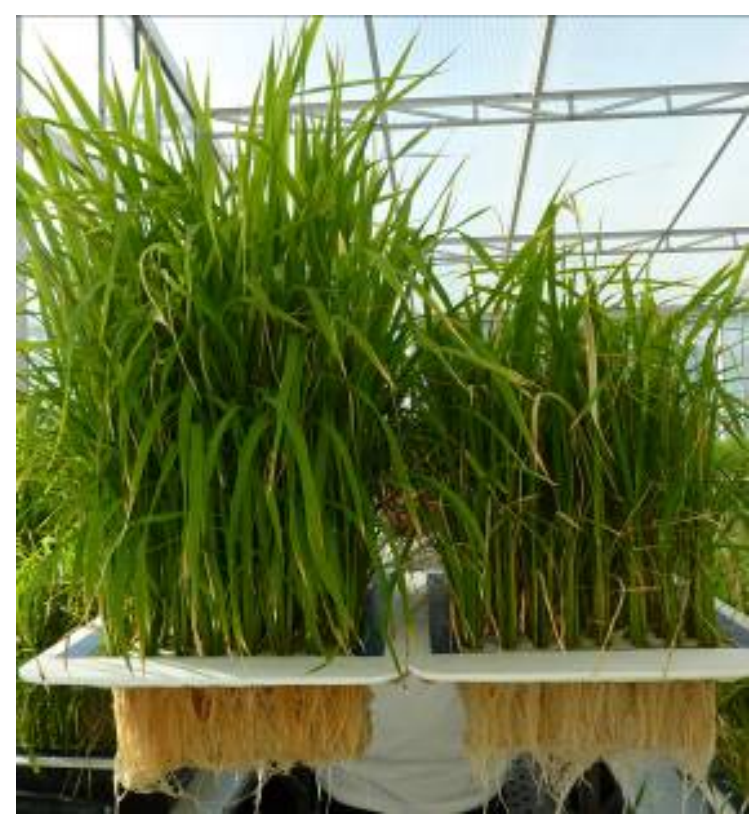

Appendix 1. Seedling stage screening of 5 rice genotypes compare with control and salinized (EC 8 dS/m) at 21 days after salinization 


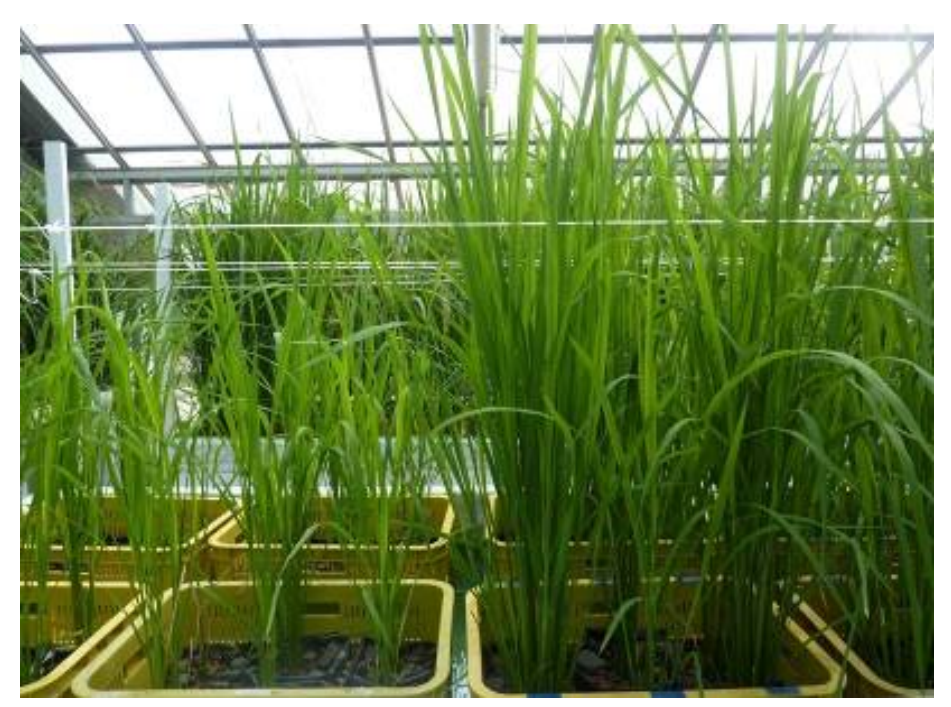

Appendix 2. Vegetative stage screening of 5 rice genotypes compare with control and salinized (EC $8 \mathrm{dS} / \mathrm{m})$ at 40 days after salinization

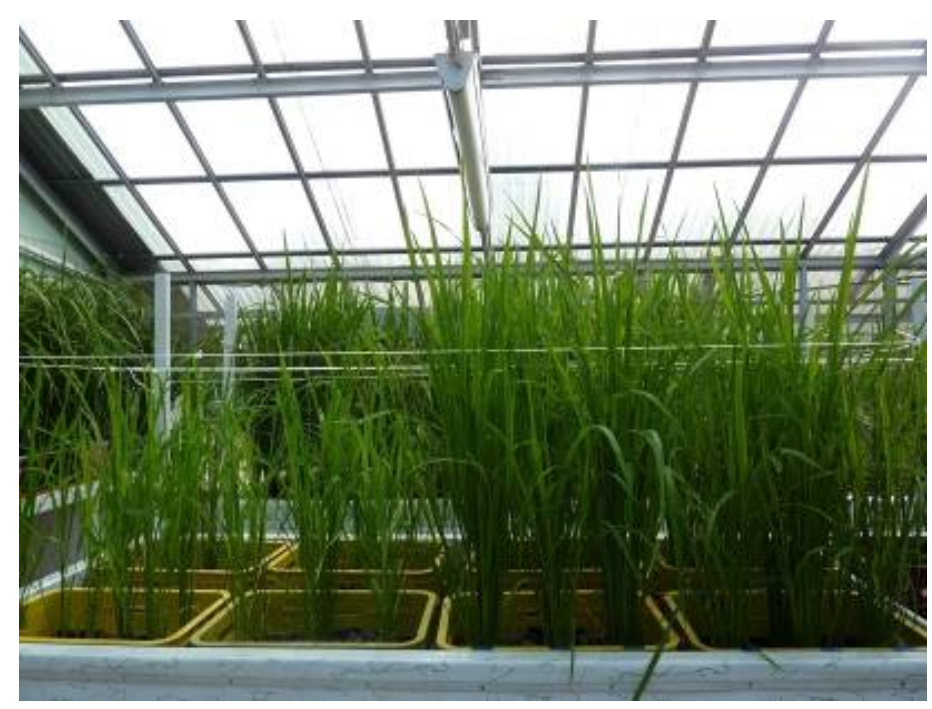

Appendix 3. Vegetative stage screening of 5 rice genotypes compare with control and salinized (EC $12 \mathrm{dS} / \mathrm{m})$ at 40 days after salinization 


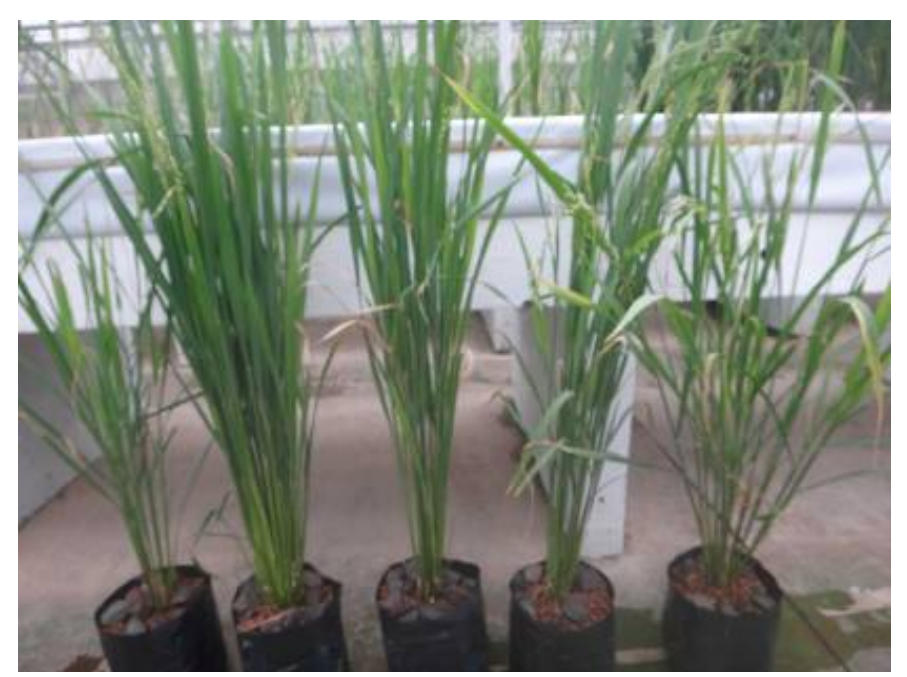

Appendix 4. Reproductive stage screening of 5 rice (Left to right: NSIC Rc222, NSIC Rc182, Binadhan-8, Binadhan-10 and IR64 respectively) genotypes salinized (EC $8 \mathrm{dS} / \mathrm{m}$ ) at 80 days aftersalinization

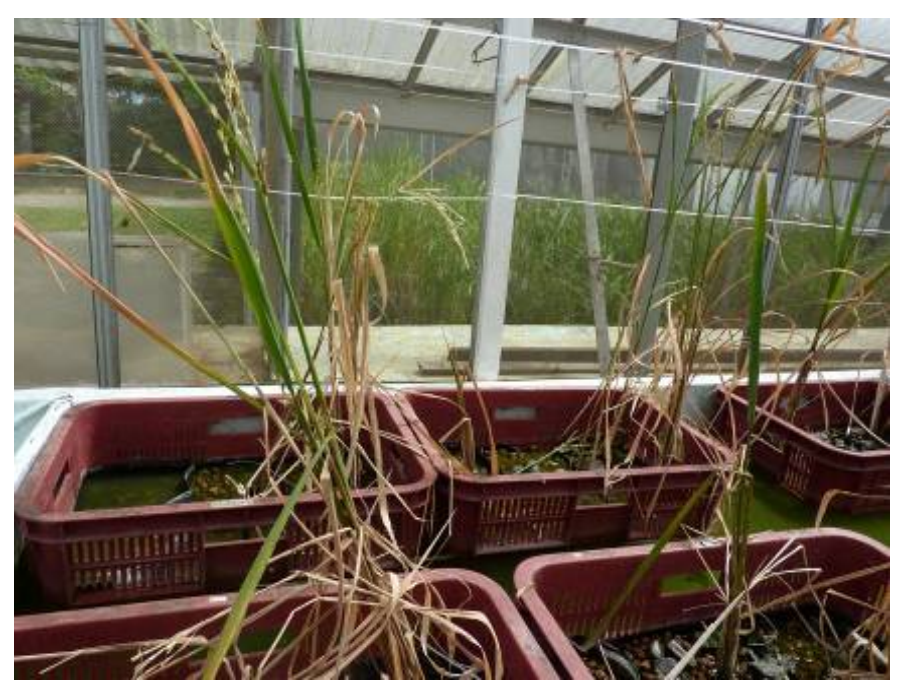

Appendix 5. Binadhan-10 survived in whole life cycle salinized (EC $8 \mathrm{dS} / \mathrm{m}$ )

\section{Copyrights}

Copyright for this article is retained by the author(s), with first publication rights granted to the journal.

This is an open-access article distributed under the terms and conditions of the Creative Commons Attribution license (http://creativecommons.org/licenses/by/3.0/). 